\title{
MOTIVATIONAL FACTORS AFFECTING RURAL WOMEN TO START-UP NEW VENTURE IN LIVESTOCK SECTOR
}

\author{
Norina Jabeen \\ $\mathrm{PhD}$ Scholar, Department of Rural Sociology, \\ University of Agriculture Faisalabad \\ norinajabeen@gmail.com \\ Ashfaq Ahmad Maan \\ Professor, Department of Rural Sociology, \\ University of Agriculture Faisalabad \\ ashfaqmaan@gmail.com \\ Izhar Ahmad Khan \\ Associate professor, Department of Rural Sociology, \\ University of Agriculture Faisalabad \\ Izhark99@yahoo.com
}

\begin{abstract}
Entrepreneurship is an engine for the economic growth of any country. Now rural people are focusing more on livestock and value-added products as compared to conventional crops. In Pakistan, livestock is a source of security and opportunity for employment and net cash for rural women. This study investigates the motivational factors affecting rural women to start up new ventures in the livestock sector. In this study, the triangulation approach was used for data collection. A multi-stage sampling technique was used for the collection of quantitative data from three districts of Punjab Pakistan through a structured interview schedule. A total of 396 women respondents were selected by using a simple random sampling technique. Study results revealed that women entrepreneurs faced many hurdles such as lack of training, credit, access to resources, freedom of mobility, and lack of decision-making power. Bivariate analysis showed that age, education, income, family support, livestock management training, micro-credit, participation in decision-making played a key role in women's entrepreneurship. Adequate training must be given to women entrepreneurs at the farm level, and guidance at all stages can be effective ways to cope with the problems of women entrepreneurs that hinder success in entrepreneurship.
\end{abstract}

Keywords: Women, livestock, Entrepreneurship, startup venture, Punjab, Pakistan

\section{INTRODUCTION}

Livestock plays a key role in fostering socio-economic growth in rural areas. Approximately eight million families are engaged in livestock-raising activities. These families generate more than 35 percent of their income from animal-based activities. It is an excellent source of net cash income. It is often only a great source of vibrant income for rural society. It performs a major and vital part in mitigating poverty. In 2017-18, livestock accounted for 58.9\% of agricultural value-added goods and $11.3 \%$ of overall GDP production (Govt. of Pakistan, 2018). Day by day, livestock development in Pakistan is growing rapidly. It is an essential part of community rural people's livelihood. It has a vast population of 72 million animals including buffaloes and cows. The country is importing raw and fine livestock products from other countries such as dry milk and other dairy products. Nowadays, the demand for livestock goods is increasing gradually due to rising per capita income; population growth, urbanization, and export opportunities (Javed, 2017). Women are performing a dynamic role in economic advancement for the country. Their presence is very prominent in several life fields, such as in the agricultural and livestock sector, organized and unorganized working spaces, and especially in industrial organizations (Gayathridevi, 2014).

\section{REVIEW OF LITERATURE}

Ekpe et al. (2010) reported that women play a fundamental role in making sustainable change for the members of their families, societies, and society, but face other challenges such as low household 
income, poverty, unemployment, and social discrimination they face. Women must face these issues, mostly in developing countries. As such, most women start work as entrepreneurial acts to support their family members. It has been revealed that women's entrepreneurship in a country can be an effective strategy for poverty decline. A Study conducted in Mandya District of India, Raghupathi (2013) found that a majority of $78.75 \%$ belonged to the middle age group (30-50 years). In the personal constraints of rural women, health issues were charted by $75 \%$, non-cooperation of family members by $73.75 \%$, lack of leisure time by $57.5 \%$, dual duties by $70 \%$. Women entrepreneurs ' associated challenge study is a difficulty in accessing networks of companies that restrict their access to information and training opportunities, create strategic alliances and enter fresh markets (Still et al., 2006; Winn, 2005; Walker, 2006). Such a challenge is more pronounced when working in farming due to the difficulty of accessing suitable tools and technology to increase their production and market their goods (Doss, 2001; Ragasa, 2012; Quisumbing \& Pandolfelli, 2010).

Tulachan and Karki (2000) observed that women face more problems in the livestock industry compared to men. They take advantage of lesser primary opportunities to participate in plans for training exercises and learning in the care of livestock and managerial matters. A large majority of women earn enough income from livestock farming for their family members. Rural women are generally aware of animal care and managerial actions because they are used to doing this work. It is a piece of routine matter that cares for and rears the animals. Continuously, rural women remain busy with livestock farming that is why they earn more money than their men. Rural females are empowered. They have the cash to spend on domestic necessities such as childcare and food. Suman (2008) noted that livestock production work is mainly in the hands of rural females. Rural females carry out most of the animal-related operations such as health care management, fodder collection, value-added, watering, household-level processing, feeding, and marketing. In recent years, rural women's involvement is increasing day by day not only in agriculture but also in its related sectors. Truly the work of animal husbandry is becoming feminized. They contribute nearly three-fourths of the labor requests in agriculture and its associated operational actions. Hoque et al., (2014) explained that women's entrepreneurship development is a necessary part of the human resource development process. Entrepreneurship among women has developed a recent and significant concern of the time. Women are aware of the reality of their rights and job position in their existence. An entrepreneur takes an interest in the farming sector as it not only provides financial support but also provides them with socially upgrading status in society. Women's entrepreneurship in Bangladesh's categorizing the major barriers for selected entrepreneurs were their family members, business issues, their society, and their religion It is the need for time to study dimensions such as administrative inferiority, financing, political, religious and culture.

Javed et al., (2006) noted that females face several hurdles as they have fewer possibilities to take advantage of opportunities. These females did not have the right to make choices on their own it is all about males; males are leading power in a society like Pakistan. This reason disturbs the performance of women in all life circles, mainly in livestock and agriculture. Due to that in the coming future days, women will have to face many more difficulties in the decision-making process. Objective: The main objective of the study was to find out the motivational factors causing the startup of a new venture by rural women in the livestock sector.

\section{MATERIALS AND METHODS}

The universe for the present study was rural areas of Punjab Pakistan. In this study, the triangulation approach was used for data collection. A multi-stage sampling technique was used for the selection of areas from the province of Punja (Agresti \& Finlay, 2008). Three districts, i.e., District Okara, District Kasur, and District Sheikhupura, were chosen from thirty-six districts of Punjab in the first phase through a simple random sampling method. These three districts had different locations and attributes that enabled the researcher to make a more representative sample. The second phase marked the selection of six tehsils from three selected districts, as two tehsils were selected by simple random sampling from each district. Tehsil Renala Khurd and Okara from the district of Okara, Tehsil Kasur and Pattoki from the district of Kasur, and Tehsil Ferozewala and Sharaqpur from the district of Sheikhupura were randomly selected. A total of 396 rural women entrepreneurs were selected for the sample. The sample size was determined through the Fitzgibbon table (Fitzgibbon and Morris, 1987). A well-structured interview schedule was primed according to the research objectives of the study. 
The target population for this study consisted of rural women entrepreneurs from the livestock business. Women with livestock as a source of livelihood, registered in CVDs (civil veterinary dispensary) with their identity cards and taking advantage of any type of opportunity offered by the livestock and dairy development Department, Punjab. A list of women entrepreneurs was made from selected CVDs at the fourth stage. The total population of women entrepreneurs was 4005 . The selection criteria for the respondent were those women who lived in villages, had livestock as a source of livelihood and registered with their identity cards in CVDs (civil veterinary dispensary), and took advantage of any type of opportunity offered by Livestock and Dairy Department Punjab (L\&DD). Using a simple random sampling technique 33 women was chosen from each CVD.

\section{Challenges Scale index}

Twelve item scales were used to measure the challenges faced by the women in livestock entrepreneurship. Each question was answered on three items Likert scale. So, the score of an individual may range from 12 to 36. This was further divided into three major categories. The score ranged from 12-20 was ranked as a low level of challenges; 21-28 was ranked as a medium while 2936 was adjusted as high-level challenges faced by the women in livestock entrepreneurship.

\begin{tabular}{|c|c|c|c|c|c|}
\hline Challenges & $\begin{array}{c}12 \text { items } \\
3 \text {-point likert } \\
\text { scale }\end{array}$ & $12-20$ & $21-28$ & $29-36$ & .902 \\
\hline
\end{tabular}

\section{RESULTS AND DISCUSSION}

\section{Univariate Analysis}

Socio-economic factors such as the age of entrepreneurs, education, experience, family type, marital status, training, and skills had been recognized as factors affecting the business success (Panda, 2008; Saleem, 2012).

Table No. 1 Age brackets of the selected entrepreneur women

\begin{tabular}{|c|c|c|}
\hline Age brackets (in years) & $F$ & $\%$ \\
\hline Up to 35 & 152 & 38.4 \\
\hline $36-45$ & 174 & 43.9 \\
\hline Above 45 & 70 & 17.7 \\
\hline Total & 396 & 100.0 \\
\hline
\end{tabular}

Table 1 indicates the age of the female entrepreneurs. The age of women entrepreneurs is divided into three groups in this respect: the 1 st category covering those up to 35 years of age, the 2 nd category falling into the $36-45$ age groups, and the 3rd category was over 45 . The $36-45$ age groups had the highest proportion (43.9 percent) among women entrepreneurs. Approximately 38 percent of female entrepreneurs were up to age 35 and 17.7 percent were over age 45. Makhijani et al. (2015) reported similar findings. They also reported that most female entrepreneurs were middle aged women. They found that about 38 percent of female entrepreneurs were between the ages of 36-45. Luqman et al. (2013) showed similar findings with most respondents being middle-aged (35-50 years of age) $(48.8 \%)$. Raghupathi (2013) found that a majority of 78.75 per cent belonged to the middle age group (30-50 years) in a study conducted in Mandya district of India.

Table No. 2 Classification of the sampled entrepreneur women concerning their educational level

\begin{tabular}{|l|c|c|}
\hline Educational Level & $F$ & $\%$ \\
\hline Illiterate & 126 & 31.8 \\
\hline Primary & 81 & 20.5 \\
\hline Middle & 120 & 30.3 \\
\hline Matric & 69 & 17.4 \\
\hline Total & 396 & 100.0 \\
\hline
\end{tabular}

Table 2 showed that most of the respondents were literate in study that indicates women's interest in education. It was observed that the male members of the study area educate their female family member enough so that they can read and write. Bhardwaj (2014) argued that high education is one of the primary sources of creative and progressive entrepreneurial concepts. Training and 
professional upgrading also favorably affect women's entrepreneurial operations. Luqman et al. (2013) revealed similar findings that the educational level of rural women in the areas was low as more than half was found to be illiterate. Meher and Sahoo, (2008) investigated that around thirty-two percent sampled women were illiterate, about one-fifth (20.5\%) were primary, slightly less than one third (30.3\%) were middle, and $17.4 \%$ sampled women were matriculated. Study revealed that degree of formal education was deemed important as formal education was always considered an important plus point in building an individual's entrepreneurial career. An entrepreneur's communication skills, technical advances, manufacturing efficiency and marketing capacity depend primarily on his / her educational level.

Table No. 3 Marital status of the entrepreneur women

\begin{tabular}{|l|c|c|}
\hline Marital status & $F$ & $\%$ \\
\hline Married & 286 & 72.2 \\
\hline Single & 8 & 2.0 \\
\hline Separated & 6 & 1.5 \\
\hline Divorced & 17 & 4.3 \\
\hline Widow & 79 & 19.9 \\
\hline Total & 396 & 100.0 \\
\hline
\end{tabular}

In addition to other specific personal characteristics such as age and education, women entrepreneurs' marital status also plays an important role in starting up the business. Considering the study results, a large percentage (72.2\%) of female entrepreneurs were married, about one-fifth (19.9\%) was widowed, only $2.0 \%$ were single, followed by $1.5 \%$ separated and $4.3 \%$ divorced. It is evident from data that married females were more involved in entrepreneurships. This may be the reason that females of the study area want to earn for their family. Makhijani et al. (2015) varied the results above. They found the single female entrepreneurs (36\%), married (25\%) and divorced (17\%), while $16 \%$ were Widow.

Motivational factors causing startup of new venture.

Table No. 4 Classification of the sampled population concerning to the reasons for entrepreneurship intention

\begin{tabular}{|l|c|c|c|c|c|c|c|c|c|}
\hline \multirow{2}{*}{ Reasons } & \multicolumn{2}{|c|}{1} & \multicolumn{2}{|c|}{2} & \multicolumn{2}{|c|}{3} & Mean & S.D. & Rank \\
\cline { 2 - 10 } & $F$ & $\%$ & $F$ & $\%$ & $F$ & $\%$ & .71 & 1 \\
\hline $\begin{array}{l}\text { Economic } \\
\text { independence }\end{array}$ & 0 & 0.0 & 88 & 22.2 & 308 & 77.8 & 2.78 & .41 \\
\hline $\begin{array}{l}\text { To support the } \\
\text { family }\end{array}$ & 0 & 0.0 & 104 & 26.3 & 292 & 73.7 & 2.74 & .44 & 2 \\
\hline $\begin{array}{l}\text { Establishing own } \\
\text { credit money }\end{array}$ & 12 & 3.0 & 120 & 30.3 & 264 & 66.7 & 2.64 & .54 & 3 \\
\hline $\begin{array}{l}\text { To upgrade the } \\
\text { status in society }\end{array}$ & 3 & 0.8 & 140 & 35.4 & 253 & 63.9 & 2.63 & .49 & 4 \\
\hline $\begin{array}{l}\text { To Achieve the } \\
\text { excellence level of } \\
\text { work }\end{array}$ & 10 & 2.5 & 167 & 42.2 & 219 & 55.3 & 2.53 & .54 & 5 \\
\hline $\begin{array}{l}\text { To get social } \\
\text { identity }\end{array}$ & 12 & 3.0 & 167 & 42.2 & 217 & 54.8 & 2.52 & .55 & 6 \\
\hline $\begin{array}{l}\text { To take } \\
\text { Confidence }\end{array}$ & 10 & 2.5 & 198 & 50.0 & 188 & 47.5 & 2.45 & .54 & 7 \\
\hline $\begin{array}{l}\text { Greater freedom } \\
\text { and mobility }\end{array}$ & 14 & 3.5 & 208 & 52.5 & 174 & 43.9 & 2.40 & .55 & 8 \\
\hline \begin{tabular}{l} 
Just to time spare \\
\hline
\end{tabular} & 123 & 31.1 & 136 & 34.3 & 137 & 34.6 & 2.04 & .81 & 9 \\
\hline
\end{tabular}

$1=$ Not at all $2=$ To some extent $3=$ To great extent

An integrated attribute of the businesswoman who can contribute values both in the family and in social life is a strong desire to do something good. Although they were primarily motivated to 
do something economic to support their husbands and share their burden, some women were also selfmotivated by their own business activities and the choice of types of firms for different reasons (Roy and Manna, 2014). The above table reflects the reasons for the intention of entrepreneurship. It was discovered that the majority of females began entrepreneurship towards financial independence

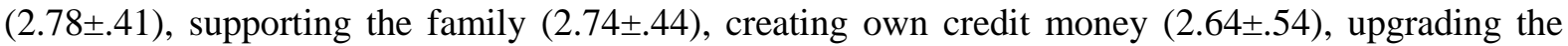

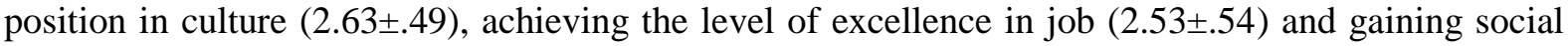
identity (2.52 .55) and falling between the categories of 'to a great extent' and 'to some extent' but tended more toward to a great extent category. And these reasons ranked $1^{\text {st }}$ to $6^{\text {th }}$, respectively. However, remaining reasons for entrepreneurship intention such to take confidence (2.45 \pm .54$)$, greater freedom and mobility $(2.40 \pm .55)$ and just to time pass $(2.04 \pm .81)$ were ranked $7^{\text {th }}$ to $9^{\text {th }}$, respectively and fell between the categories of 'to a great extent' and 'to some extent' but tended more toward to some extent category. It means that most women have started entrepreneurship for economic independence, supporting the family, setting up their own credit money, and upgrading the status in society. ILO (2003) had found similar findings. They confirmed that women's main motivating factors in starting their own businesses were supporting their families, being selfemployed, and generating their own income. Personal savings and family loans / contributions were the main financial sources for the start-up and growth of women-operated enterprises. It was concluded during the focus group discussions that most women began entrepreneurship for financial independence, supporting the family, setting up their own credit money and upgrading their role in society.

Table No. 5 Ranking order of entrepreneurship's role in building women empowerment

\begin{tabular}{|l|c|c|c|}
\hline Role of Entrepreneurship & Mean & S.D. & Rank \\
\hline Economic freedom & 4.58 & .78 & 1 \\
\hline Improved standard of living & 4.46 & .87 & 2 \\
\hline Self-confidence & 4.26 & .89 & 3 \\
\hline Increased social interaction & 4.13 & .98 & 4 \\
\hline Sense of achievement & 4.10 & 1.02 & 5 \\
\hline Enhance awareness & 4.02 & .97 & 6 \\
\hline Decision-making capacity in family and community & 4.02 & 1.04 & 7 \\
\hline Increased participation in social meetings & 3.95 & 1.01 & 8 \\
\hline $\begin{array}{l}\text { Involvement in solving problems related to women } \\
\text { and community }\end{array}$ & 3.94 & 1.04 & 9 \\
\hline Development in leadership qualities & 3.93 & 1.12 & 10 \\
\hline Engaged in political activities & 3.20 & 1.60 & 11 \\
\hline
\end{tabular}

The ranking of women's empowerment in various dimensions is listed in the table 5 which

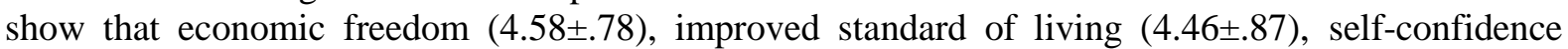

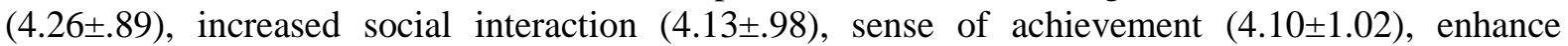
awareness (4.02 \pm .97$)$ and decision-making capacity in family and community (4.02 \pm 1.04$)$ were ranked $1^{\text {st }}$ to $7^{\text {th }}$, respectively, and fell between the categories of very high and high but tended more toward high category. However, Increased participation in social meetings $(3.95 \pm 1.01)$, involvement in solving the problems related to women and community (3.94 \pm 1.04$)$, development in leadership qualities $(3.93 \pm 1.12)$ and engaged in political activities $(3.20 \pm 1.60)$ were ranked $8^{\text {th }}$ to $11^{\text {th }}$, respectively.

Table 6 represented relation association among age of the entrepreneur women and their entrepreneurial achievement. $\chi^{2}$ value $\left(\chi^{2}=9.09\right)$ a significant $(p=.051)$ which describes association among age of the entrepreneur women and their entrepreneurial achievement. $\chi 2$ value showed a significant and positive relation among the variables. The value of positive Gemma test showed that the relationship between variables is positive. Hence, it is concluded that as the age of the women entrepreneurs increases, their entrepreneurial achievements also increase. 
Bi-Variate Analysis

Table No. 6 Relation among age of the entrepreneur women and their entrepreneurial achievement

\begin{tabular}{|l|c|c|c|c|}
\hline \multirow{2}{*}{ Age (in years) } & \multicolumn{3}{|c|}{ Entrepreneur's achievements } & \multirow{2}{*}{ Total } \\
\cline { 2 - 5 } & Low & Medium & High & \\
\hline \multirow{3}{*}{ Up to 35 } & 34 & 84 & 34 & 152 \\
\cline { 2 - 5 } & $22.4 \%$ & $55.3 \%$ & $22.4 \%$ & $100.0 \%$ \\
\cline { 2 - 5 } & 22 & 100 & 52 & 174 \\
\hline \multirow{2}{*}{ Above 45 } & $12.6 \%$ & $57.5 \%$ & $29.9 \%$ & $100.0 \%$ \\
\cline { 2 - 5 } & $21.4 \%$ & 32 & 23 & 70 \\
\hline Total & 71 & $45.7 \%$ & $32.9 \%$ & $100.0 \%$ \\
\cline { 2 - 5 } & $17.9 \%$ & $54.5 \%$ & 109 & 396 \\
\hline
\end{tabular}

Chi-square $(\chi 2)$ value $=9.09 \quad$ d.f. $=4 \quad$ P-value $=.051^{*} \quad$ Gamma $(\lambda)$ value $=.157$ P-value $=$ $.053 * *=$ Significant

It tells that majority of higher age (above 45) entrepreneur women were having more entrepreneurial achievements as compared to young entrepreneur. So, the null-hypothesis is rejected and alternate hypothesis i.e. "Age of the entrepreneur women is associated with their entrepreneurial achievements" is accepted. Similar results were found by Seemaprakalpa (2013). She explained that age is positively and significantly correlated with the entrepreneurial achievements.

Table No. 7 Relation among education level of the entrepreneur women and their entrepreneurial achievement

\begin{tabular}{|l|c|c|c|c|}
\hline \multirow{3}{*}{ Education } & \multicolumn{3}{|c|}{ Entrepreneur's achievements } & \multirow{2}{*}{ Total } \\
\cline { 2 - 4 } & Low & Medium & High & \\
\cline { 2 - 5 } & 24 & 71 & 31 & 126 \\
\hline \multirow{3}{*}{ Primary } & $19.0 \%$ & $56.3 \%$ & $24.6 \%$ & $100.0 \%$ \\
\cline { 2 - 5 } & 28 & 47 & 6 & 81 \\
\hline \multirow{3}{*}{ Middle } & $34.6 \%$ & $58.0 \%$ & $7.4 \%$ & $100.0 \%$ \\
\cline { 2 - 5 } & 15 & 62 & 43 & 120 \\
\hline Matric & $12.5 \%$ & $51.7 \%$ & $35.8 \%$ & $100.0 \%$ \\
\hline Total & 4 & 36 & 29 & 69 \\
\cline { 2 - 5 } & $5.8 \%$ & $52.2 \%$ & $42.0 \%$ & $100.0 \%$ \\
\cline { 2 - 5 } & 71 & 216 & 109 & 396 \\
\hline
\end{tabular}

Chi-square $(\chi 2)=41.32$ d.f. $=6 \mathrm{P}$-value $=.000 * * \quad(\lambda)$ value $=.258 * *=$ Highly significant

Table 7 represented relation among education of the entrepreneur women and their entrepreneurial achievement. X2 value (41.32) a highly significant $(p=.000)$ which describes association among education of the entrepreneur women and their entrepreneurial achievement. $(\lambda)$ Value of statistics showed a significant and positive relation among the variables. It tells that majority of educated (middle and matric) entrepreneur women were having more eentrepreneurial achievements as compared to illiterate entrepreneur.

Table No. 8 Relation among women empowerment and their entrepreneurial achievement

\begin{tabular}{|l|c|c|c|c|}
\hline \multirow{2}{*}{$\begin{array}{l}\text { Women } \\
\text { empowerment }\end{array}$} & \multicolumn{3}{|c|}{ Entrepreneur's achievements } & \multirow{2}{*}{ Total } \\
\cline { 2 - 5 } & Low & Medium & High & \\
\cline { 2 - 5 } & 28 & 23 & 6 & 57 \\
\hline \multirow{2}{*}{ Medium } & $49.1 \%$ & $40.3 \%$ & $10.5 \%$ & $100.0 \%$ \\
\hline \multirow{2}{*}{ High } & 38 & 87 & 26 & 151 \\
\cline { 2 - 5 } & $25.2 \%$ & $57.6 \%$ & $17.2 \%$ & $100.0 \%$ \\
\hline Total & 5 & 106 & 77 & 188 \\
\cline { 2 - 5 } & $2.6 \%$ & $56.4 \%$ & $41.0 \%$ & $100.0 \%$ \\
\cline { 2 - 5 } & $11.9 \%$ & 216 & 109 & 396 \\
\hline
\end{tabular}

Chi-square $(\chi 2)$ value $=97.22 \quad$ d.f. $=4$ P-value $=.000 * * \quad \Lambda$ value $(\lambda)$ value $=.672 \quad * *=$ Highly significant 
The value of positive Gemma test showed that the relationship between variables is positive. Hence, it is concluded that as the education of the women entrepreneurs increases, their entrepreneurial achievements also increase. So, the null-hypothesis is rejected and alternate hypothesis i.e. "Education of the entrepreneur women is associated with their entrepreneurial achievements" is accepted.

Table 8 represents relation among women empowerment and their entrepreneurial achievement. $(\chi 2=97.22)$ a highly significant $(p=.000)$ which describes association among women empowerment and their entrepreneurial achievement. The value of Gemma statistic showed a significant and positive relationship among the variables. It tells that the majority of those women who had high-level empowerment were having more entrepreneurial achievements as compared to those women who had less empowerment. It is clear from the above findings, women who had less empowerment having low (49.1\%), medium (40.3\%) and high (10.5\%) level entrepreneurial achievement; on the other hand high empowered women were having low (2.6\%), medium (56.4\%) and high $(41.0 \%)$ level entrepreneurial achievement. So, the null-hypothesis $\mathrm{H}_{0}$ is rejected and hypothesis $\mathrm{H}_{1}$ "Women empowerment is associated with their entrepreneurial achievements" is accepted.

\section{CONCLUSION}

The study results showed that women were principally responsible for livestock management in their households. The research showed the importance of livestock in Pakistan's agricultural economy and the considerable scope for enlargement by making greater use of women's capabilities. It was found that entrepreneur women faced many challenges. The majority of the women faced a shortage of

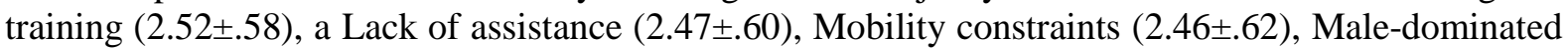

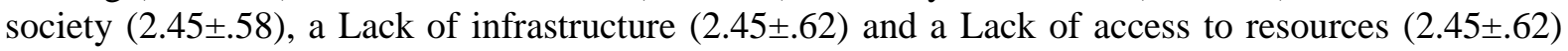
and these obstacles were respectively ranked 1 st to 6 th. Most of the women faced a Lack of proper

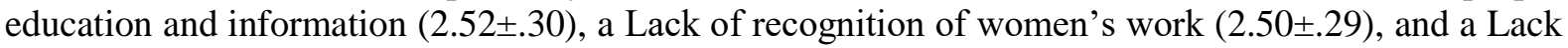

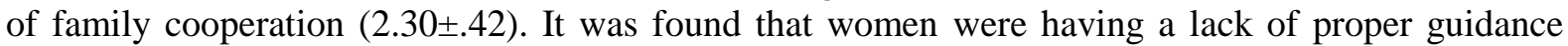

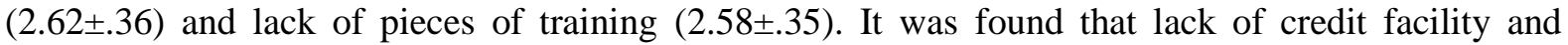
complex loaning procedures were the major issues faced by the women. A major part $(47.5 \%)$ of entrepreneur women was satisfied and 36.1 percent were highly satisfied regarding their entrepreneurship. A large proportion (53.8 percent) of women entrepreneurs was pleased with their work and 28.3 percent were highly satisfied. Chi-square analysis shows that there was a significant and positive relationship between age, education, family structure, income, working experience, training, credit, awareness of modern management technique, awareness about livestock government services, role of mass media in generating awareness. However, challenges in entrepreneurship were negatively associated with the entrepreneur's achievements.

\section{RECOMMENDATIONS}

To promote entrepreneurship at the field level, family cooperation must be provided. It is important to recognize women involved in entrepreneurship at all stages.

O Need to train women's groups in risk management.

O Need for alternative models of supplying insured animals for female entrepreneurs in Mandi.

O Insurance coverage is required for initiatives to avoid unexpected losses.

O New ventures require better technical training and continuous support.

- Need for installment provision of animals.

\section{REFERENCES}

Agresti, A., \& Finlay, B. (2008). Statistical options for the social sciences, 4th Ed. (Upper Saddle River, NJ: Prentice Hall.

Doss, C. R. (2001). Designing agricultural technology for African women farmers, Lessons from 25 years of experience. World development 29(12): 2075-2092.

Ekpe, I., Mat, N.B., \& Razak, R.C. (2010). The effect of microfinance factors on women entrepreneurs' performance in Nigeria: A conceptual framework. International Journal of Business and Social Science, 1(2): 255-263. 
Fitzgibbon, C. T., \& Morris, L.M. (1987). Determining sample size from the given population. Newbury Park CA: Sage Publications.

Gayathridevi, C. L. (2014). Barriers of Women Entrepreneurs: A Study in Bangalore Urban District. International Journal of Trends in Economics Management and Technology, 3(2): 24-30.

GOP. (2018). Economic Survey of Pakistan 2017-18. Economic Advisory Wing, Finance Division, Islamabad, Pakistan.

Hoque, M. J., Rahman, M.A., \& Razia, S. (2014). Women Entrepreneurship Development under Islamic Perspective-A Study on Some Selected Muslim Women Entrepreneurs of Bangladesh. World Review of Business Research, 4(3): 45-63.

International Labour Organization ILO (2003). Ethiopian Women Entrepreneurs: Going for Growth. Geneva: International Labour Office.

Javed, A., Sadaf, S., \& Luqman, M. (2006). Rural women's participation in crop and livestock production activities in Faisalabad Pakistan. Journal of Agriculture and Social Science, 2 (3): $150-154$.

Javed, M. A. (2017). National Food Security Policy Government of Pakistan Ministry of National Food Security and Research Islamabad.

Luqman, M., Shahbaz, B., Khan, I. A., \& Safdar, U. (2013). Training need assessment of rural women in livestock management-case of Southern Punjab, Pakistan. Journal of Agricultural Research. 51(1): 99-108

Makhijani, H. B., Kumbhar, M. I., Mughal, S., \& Talpur, U. (2015). Women Entrepreneurship: Problems Faced by Rural Women Entrepreneurs in Sindh Province of Pakistan. Journal of Basic and Applied Sciences, 1(11): 274-277.

Meher, R., \& Renubala, S. (2008). Socioeconomic Background of Entrepreneurs and the Industrial Climate of the Small-Scale Sector Industries in Orissa. The Journal of Entrepreneurship, $17(2): 1-171$

Panda, T. K. (2008). Entrepreneurial success key indicator analysis in Indian context. 1(1): 1-10.

Quisumbing, A. R., \& Lauren, P. (2010) Promising approaches to address the needs of poor female farmers: Resources, constraints, and interventions. World Development, 38 (4): 581-592.

Ragasa, C. (2012) Gender and institutional dimensions of agricultural technology adoption. 1(1):1824.

Raghupathi, D. (2013). A study on entrepreneurial behavior of women entrepreneurs in mandya district, $1(1): 1-20$.

Saleem, M. A. (2012). The impact pf socio-economic factors on small business success. Malaysian Journal of Society and Space, 8(1): 24-29.

Seemaprakalpa, S. (2013). Socio-economic variables and their correlation with entrepreneurial behavior of women entrepreneurs. Adv. Res. J. Soc. Sci., 4 (2): 143-147.

Still, L. V., \& Elizabeth, A. W. (2006) The self-employed woman owner and her business: An Australian profile. Women in Management review, 21(4): 294-310.

Suman, M. (2008) Participation of rural women under household and farm activities. Indian Journal of Agricultural Research, 42(1): 37-41.

Tulachan, M., \& Karki, S. (2000) Gender and Livestock Management in Mixed Farming Systems. ICIMOD Newsletter, 1(37): 1-10.

Walker, H. (2006). The virtual organization: a new organizational form? International Journal of Networking and Virtual Organizations, 3(1): 25-41.

Winn, J. (2005). Women entrepreneurs: can we remove the barriers. The International Entrepreneurship and Management Journal 1(3): 381-397. 